\title{
Pengaruh Kompres Panas dan Dingin terhadap Penurunan Nyeri Kala I Fase Aktif Persalinan Fisiologis Ibu Primipara
}

\author{
Mutia Felina ${ }^{1}$, Masrul $^{2}$, Detty Iryani ${ }^{3}$
}

\begin{abstract}
Abstrak
Persalinan adalah peristiwa fisiologis dalam setiap perkembangan seorang wanita menjadi ibu.Peristiwa ini dapat menimbulkan trauma karena nyeri yang dialaminya.Beberapa ibu bahkan memilih untuk melahirkan secara sectio caesareatanpa indikasi medis untuk menghindari nyeri tersebut. Terapi kompres panas dan dingin merupakan salah satu metode non farmakologis untuk mengatasi nyeri.Tujuan penelitian ini adalah untuk mengetahui pengaruh pemberian kompres panas dan dingin terhadap penurunan nyeri kala I fase aktif persalinan fisiologis ibu primipara. Jenis penelitian ini yaitu eksperimental dengan rancangan One Group Pretest Postest. Penelitian dilaksanakan di BPS Bunda dan BPS Rita Bukittinggi tanggal 26 Maret s/d 26 Mei 2014.Populasi penelitian ini adalah ibu primipara inpartu kala I fase aktif menggunakan tekhnik Non Probability Sampling dengan metode sampel Consecutive Sampling. Dari hasil penelitian diperoleh rerata derajat nyeri sebelum kompres panas adalah $7,29 \pm 1,102$ dan sebelum kompres dingin adalah $7,33 \pm 1,238$. Rerata derajat nyeri setelah kompres panas adalah $4,95 \pm 1,244$ dan setelah kompres dingin adalah $3,90 \pm 0,889$. Tidak terdapat perbedaan rerata derajat nyeri sebelum kompres panas dandingin $p=0,896$. Terdapat perbedaan rerata derajat nyeri setelah kompres panas dan dingin $p=0,003$. Terdapat perbedaan selisih derajat nyeri kompres panas dan dingin $p=0,001$. Dapat disimpulkan terdapat perbedaan pengaruh pemberian kompres panas dan dingin terhadap penurunan nyeri persalinan.
\end{abstract}

Kata kunci: kompres panas, kompres dingin, nyeri persalinan

\begin{abstract}
Childbirth is a physiologic process that happened in each woman's development to be a mother. This process may cause trauma because of the pain. Even, some mother choose sectio caesarea without medical implication as a labor choice. Hot and cold compress therapy is one of non-pharmacological approach to reduce pain. The objective of this study was to determine the difference of the effect of hot and cold compress pain relief during active first stage of physiologic labor in primiparous women.This is an experimental study with one group pretest posttest design. This study takes places in BPS Bunda and BPS Rita in Bukittinggi from $26^{\text {th }}$ of March till $26^{\text {th }}$ of May, 2014. The population of this study was inpartu primiparous women in active first stage of labor using non probability sampling and consecutive sampling method. The result of this study are mean rate of the pain before hot compress are 7.29 \pm 1.102

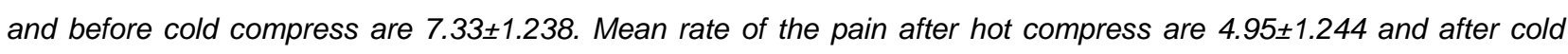
compress are 3.90 \pm 0.889 . There is no differences of the pain during labor before hot and cold compress $p=0.896$. There is differences of the pain during labor after hot and cold compress $p=0,003$. There is differences of the pain deviation in hot compress and cold compress $p=0.001$. We conclude that there is the difference of the effect of hot and cold compress on pain relief during labor.
\end{abstract}

Keywords: hot compress, cold compress, pain during labor

Affiliasi penulis : 1. Program Studi Magister Kebidanan FK UNAND (Fakultas Kedokteran Universitas Andalas Padang), 2. Bagian IImu Gizi FK UNAND, 3. Bagian Fisiologi FK UNAND
Korespondensi : Mutia Felina, Jl.Sijolang Dt.P.Basa No.78 B Stasiun Kota Bukittinggi, Sumatera Barat, E-mail: felina_cweet@yahoo.com, Telp: 082172207114 


\section{PENDAHULUAN}

Kehamilan, persalinan dan masa nifas adalah peristiwa fisiologis dalam setiap perkembangan seorang wanita menjadi ibu. Peristiwa fisiologis ini terkadang dapat menimbulkan trauma pada ibu karena nyeri yang dialaminya. Beberapa ibu bahkan ada yang trauma untuk hamil dan melahirkan lagi karena takut akan mengalami nyeri yang sama. Bagi ibu yang pernah melahirkan, nyeri persalinan merupakan nyeri yang paling menyakitkan apalagi bagi ibu-ibu yang baru pertama kali merasakannya. ${ }^{1}$

Rasa nyeri pada persalinan dalam hal ini adalah nyeri kontraksi uterus yang dapat mengakibatkan peningkatan aktifitas sistem saraf simpatis, perubahan tekanan darah, denyut jantung, pernafasan dan apabila tidak segera diatasi maka akan meningkatkan rasa khawatir, tegang, takut dan stress. Nyeri pada ibu bersalin juga menyebabkan meningkatnya kadar katekolamin atau hormon stres seperti epinefrin dan kortisol. Peningkatan kadar katekolamin atau hormon stres dapat mengurangi kemampuan tubuh menahan rasa nyeri. ${ }^{2,3}$

Pengelolaan nyeri persalinan adalah salah satu tujuan utama perawatan bersalin. Tujuan keseluruhan dalam pengobatan nyeri adalah mengurangi nyeri sebesar-besarnya dengan kemungkinan efek samping paling kecil. ${ }^{4,5}$

Penatalaksanaan dalam mengatasi nyeri persalinan berdasarkan penelitian di sembilan rumah sakit di Amerika Serikat tahun 1996, sebanyak 4171 pasien, yang persalinannya ditolong oleh perawatbidan menggunakan beberapa tipe penatalaksanaan nyeri untuk mengatasi nyeri. lbu bersalin tersebut sekitar 90\% diantaranya memilih metode non farm akologis untuk mengatasi nyeri. ${ }^{6}$

Terapi kompres panas dan dingin merupakan salah satu metode non farmakologis untuk mengatasi nyeri.Terapi ini perlu diberikan bagi semua ibu melahirkan sebagai salah satu intervensi terapi nyeri di pelayanan kesehatan yakni rumah sakit, puskesmas maupun klinik bersalin. ${ }^{6}$ Metode non farmakologis merupakan metode yang paling sering digunakan untuk mengurangi nyeri. Metode ini mempunyai resiko yang sangat rendah, bersifat murah, simpel, efektif, tanpa efek yang merugikan dan dapat meningkatkan kepuasan selama persalinan. ${ }^{7}$

Anestesi lokalakan memblok rasa sakit di rahim, leher rahim dan bagian atas vagina. Namun demikian, otot panggul masih tetap dapat melakukan gerakan rotasi kepala bayi untuk keluar melalui jalan lahir. $^{2}$ Pengurangan nyeri persalinan juga tetap mempertahankan beberapa sensasi kontraksi uterus dan kemampuan untuk mengejan. ${ }^{8}$

Sebagian besar ibu inpartu yang mengalami rasa nyaman dalam proses persalinan kala I fase aktif adalah yang diberi kompres air hangat. Ada pengaruh yang signifikan antara pemberian kompres hangat terhadap nyeri persalinan kala I fase aktif. ${ }^{9,10}$

Penelitian yang pernah dilakukan tidak memisahkan subjek penelitian antara ibu primipara dengan multipara, sementara nyeri tersebutjuga dipengaruhi oleh pengalaman terdahulu dan hanya meneliti mengenai pemberian kompres panas. Berdasarkan fenomena diatas dan mengingat pentingnya memberikan rasa nyaman atas rasa nyeri agar tidak terjadi penyulit selama persalinan dan mudahnya teknik kompres panas dan dingin, maka penulis tertarik untuk melakukan penelitian lebih lanjut mengenai pengaruh kompres panas dan dingin terhadap penurunan nyeri kala I fase aktif persalinan fisiologis ibu primipara.

\section{METODE}

Jenis penelitian ini yaitu Experimental dengan rancangan One Group Pretest Postest. Penelitian ini dilaksanakan di BPS Bunda dan BPS Rita Kota Bukittinggi mulai tanggal 26 Maret s/d 26 Mei 2014.

Populasi dalam penelitian ini adalah ibu primipara inpartu kala 1 fase aktif. Penelitian ini menggunakan teknik non probability sampling dengan metode pengumpulan sampel consecutive sampling. Jumlah sampel untuk masing-masing kelompok adalah 21 orang.

Analisa data menggunakan analisa univariat dan bivariat Paired Samples $t$ Test dan $t$ Test Independent. Data diolah secara komputerisasi menggunakan program SPSS dengan derajat kepercayaan $95 \%$. 
HASIL

Tabel 1. Karakteristik Responden

\begin{tabular}{lccc}
\hline Karakteristik & $\begin{array}{c}\text { Kompres } \\
\text { Panas } \\
\text { Rerata } \pm \text { SD }\end{array}$ & $\begin{array}{c}\text { Kompres } \\
\text { Dingin } \\
\text { Rerata } \pm \text { SD }\end{array}$ & $\boldsymbol{p}$ \\
\hline Umur & $25,14 \pm 3,321$ & $25,43 \pm 3,544$ & $>0,05$ \\
Pembukaan & $6,38 \pm 1,071$ & $6,76 \pm 1,044$ & $>0,05$ \\
Usia Kehamilan & $38,90 \pm 0,625$ & $38,95 \pm 0,805$ & $>0,05$ \\
\hline
\end{tabular}

Berdasarkan hasil test of normality pada tabel 1 di atas, data karakteristik responden memiliki skor > 0,05 yang berarti data berdistribusi normal atau homogeny, maka uji statistik yang digunakan adalah $t$ test independent. Berdasarkan hasil uji analisa bivariat pada data karakteristik responden, dapat disimpulkan bahwa tidak terdapat perbedaan karakteristik antara kelompok kompres panas dan kompres dingin.

Tabel 2. Distribusi Derajat Nyeri Sebelum Diberikan Kompres Panas dan Kompres Dingin

\begin{tabular}{llccc}
\hline & n & Rerata & SD & $\begin{array}{c}\text { Median } \\
\text { (Min- } \\
\text { Mak) }\end{array}$ \\
& & & & $7(5-9)$ \\
Kompres Panas & 21 & 7,29 & 1,102 & $7(4-9)$ \\
\hline
\end{tabular}

Tabel 2 diatas menunjukkan bahwa rerata derajat nyeri sebelum diberikan kompres panas adalah $7,29 \pm 1,102$ dan sebelum diberikan kompres dingin adalah $7,33 \pm 1,238$.

Tabel 3. Distribusi Derajat Nyeri Setelah Diberikan Kompres Panas dan Kompres Dingin

\begin{tabular}{lcccc}
\hline & n & Rerata & SD & $\begin{array}{c}\text { Median } \\
\text { (Min- } \\
\text { Mak) }\end{array}$ \\
\hline Kompres Panas & 21 & 4,95 & 1,244 & $5(3-7)$ \\
Kompres Dingin & 21 & 3,90 & 0,889 & $4(3-6)$ \\
\hline
\end{tabular}

Tabel 3 diatas menunjukkan bahwa rerata derajat nyeri setelah diberikan kompres panas adalah
4,95 $\pm 1,244$ dan setelah diberikan kompres dingin adalah $3,90 \pm 0,889$.

Tabel 4. Penurunan Derajat Nyeri Sebelum dan Setelah Diberikan Kompres Panas

\begin{tabular}{lccc}
\hline & $\mathbf{n}$ & Rerata \pm SD & $\boldsymbol{p}$ \\
\cline { 1 - 3 } Nyeri Sebelum Kompres Panas & 21 & $7,29 \pm 1,102$ & \multirow{2}{*}{0,00} \\
\cline { 1 - 3 } Nyeri Setelah Kompres Panas & 21 & $4,95 \pm 1,244$ & \\
\hline
\end{tabular}

Tabel 4 menunjukkan bahwa terdapat pengaruh pemberian kompres panas terhadap penurunan nyeri kala I fase aktif persalinan fisiologis dengan nilai $p 0,000$.

Tabel 5. Penurunan Derajat Nyeri Sebelum dan Setelah Diberikan Kompres Dingin

\begin{tabular}{lccc}
\hline & $\mathbf{n}$ & Rerata \pm SD & $\boldsymbol{p}$ \\
\cline { 1 - 2 } Nyeri Sebelum Kompres Dingin & 21 & $7,33 \pm 1,238$ & \\
\cline { 1 - 3 } & 0,000 & \\
\cline { 1 - 3 } Nyeri Setelah Kompres Dingin & 21 & $3,90 \pm 0,889$ & \\
\hline
\end{tabular}

Tabel 5 menunjukkan bahwa terdapat pengaruh pemberian kompres dingin terhadap penurunan nyeri kala I fase aktif persalinan fisiologis dengan nilai $p 0,000$.

Tabel 6. Perbedaan Penurunan Derajat Nyeri Sebelum dan Setelah Diberikan Kompres Panas dan Kompres Dingin

\begin{tabular}{|c|c|c|c|c|c|}
\hline & \multicolumn{2}{|c|}{ Kompres Panas } & \multicolumn{2}{|c|}{ Kompres Dingin } & \multirow{2}{*}{$p$} \\
\hline & $n$ & Rerata \pm SD & $\mathbf{n}$ & Rerata \pm SD & \\
\hline \multicolumn{6}{|l|}{ Nyeri } \\
\hline Sebelum & 21 & $7,29 \pm 1,102$ & 21 & $7,33 \pm 1,238$ & 0,896 \\
\hline \multicolumn{6}{|l|}{ Kompres } \\
\hline \multicolumn{6}{|l|}{ Nyeri } \\
\hline Setelah & 21 & $4,95 \pm 1,244$ & 21 & $3,90 \pm 0,889$ & 0,003 \\
\hline Kompres & & & & & \\
\hline
\end{tabular}

Tabel 6 menunjukkan bahwa tidak terdapat perbedaan derajat nyeri sebelum diberikan kompres panas dan kompres dingin dengan nilai $p 0,896$. 
Tabel 7. Perbedaan Selisih Derajat Nyeri Sebelum dan Setelah Diberikan Kompres Panas dan Kompres Dingin

\begin{tabular}{cccccc}
\hline & \multicolumn{2}{c}{ Kompres Panas } & \multicolumn{2}{l}{ Kompres Dingin } & \multirow{2}{*}{$\boldsymbol{p}$} \\
\cline { 2 - 4 } & $\mathbf{n}$ & Rerata \pm SD & $\mathbf{n}$ & Rerata \pm SD & \\
\hline $\begin{array}{c}\text { Selisih } \\
\text { Nyeri }\end{array}$ & & & & & \\
$\begin{array}{c}\text { Sebelum } \\
\text { dan }\end{array}$ & 21 & $2,33 \pm 0,658$ & 21 & $3,38 \pm 1,117$ & 0,001 \\
Setelah & & & & & \\
Kompres & & & & & \\
\hline
\end{tabular}

Tabel 7 diatas menunjukkan bahwa terdapat perbedaan selisih derajat nyeri sebelum dan setelah diberikan kompres panas dan kompres dingin dengan nilai $p 0,001$.

\section{PEMBAHASAN}

\section{Penurunan Derajat Nyeri Sebelum Dan Setelah Diberikan Kompres Panas}

Penelitian ini memperlihatkan bahwa terdapat pengaruh pemberian kompres panas terhadap penurunan nyeri kala I fase aktif persalinan fisiologis ibu primipara dengan nilai $p 0,000$.

$\mathrm{Hal}$ ini sejalan dengan penelitian yang dilakukan Khusniyah tahun 2011 bahwa terdapat pengaruh stimulasi kulit dengan tekhnik kompres panas terhadap nyeri kala I faseaktif persalinan fisiologis dengan nilai $p 0,003 .{ }^{1}$

Manurung tahun 2011 mendapatkan hasi bahwa ada perbedaan bermakna antara derajat nyeri sebelum dan sesudah diberikan kompres panas dengan nilai $p=0,002{ }^{6}$

Yani tahun 2012 mendapatkan hasil bahwa terdapat pengaruh pemberian kompres panas terhadap rasa nyaman ibu inpartu kala I fase aktif dengan nilai $p=0,04$. Kompres air hangat yang diberikan pada punggung bawah wanita di area tempat kepala janin menekan tulang belakang akan mengurangi nyeri, panas akan meningkatkan sirkulasi ke area tersebut sehingga memperbaiki anoksia jaringan yang disebabkan oleh tekanan. ${ }^{9}$

Penelitian yang dilakukan oleh Novitasari tahun 2011 menunjukkan bahwa ada pengaruh yang signifikan antara pemberian kompres panas terhadap nyeri persalinan kala 1 fase aktif dengan nilai $p=$ $0,000 .^{10}$
Pemanasan merupakan metode sederhana yang digunakan pada ibu untuk meredakan rasa sakit. ${ }^{11}$ Stimulasi kulit melalui pemberian kompres ini dapat memberikan efek penurunan nyeri yang efektif. $^{12}$

Sebagian besar ibu inpartu mengalami rasa nyaman setelah diberikan kompres panas. Kompres panas yang diberikan pada punggung bagian bawah ibu di area tempat kepala janin menekan tulang belakang kepala akan mengurangi nyeri, panas akan meningkatkan sirkulasi ke area tersebut sehingga memperbaiki anoksia jaringan yang disebabkan oleh tekanan.

Kompres panas terbukti efektif dalam menurunkan nyeri persalinan. Pada saat penelitian, penulis juga melakukan komunikasi dengan responden pada saat kompres diberikan. Peneliti selalu mengevaluasi setiap tindakan yang dilakukan. Selalu menanyakan apakah responden merasa risih karna adanya benda asing yang diletakkan di punggungnya. Atau bagaimanakah perasaan responden pada saat ini, adakah pengaruh pemberian kompres ini atau tidak.

Secara keseluruhan berdasarkan apa yang telah peneliti observasi, semua responden rata-rata mengatakan bahwa nyeri persalinan yang dirasakannya berkurang. Walaupun respon yang diberikan berbeda-beda. Ini bisa jadi disebabkan oleh faktor-faktor lain yang mempengaruhi nyeri seseorang yang belum peneliti kendalikan, seperti suku bangsa, pekerjaan, kondisi psikologis dan faktor lainnya.

\section{Penurunan Derajat Nyeri Sebelum Dan Setelah Diberikan Kompres Dingin}

Dari hasil penelitian dapat diketahui bahwa ada pengaruh pemberian kompres dingin terhadap penurunan nyeri kala I fase aktif persalinan fisiologis ibu primipara dengan nilai $p 0,000$.

Hasil ini sejalan dengan penelitian Khusniyah tahun 2011 dengan hasil bahwa terdapat pengaruh pemberian kompres dingin terhadap penurunan nyeri kala I fase aktif persalinan fisiologis dengan nilai $p$ $0,001{ }^{1}$

Banyak pasien dan anggota tim kesehatan cenderung memandang obat sebagai satu-satunya metode untuk menghilangkan nyeri. Namun begitu, 
banyak aktivitas keperawatan non farmakologis yang dapat membantu dalam menghilangkan nyeri. Metode pereda nyeri non farmakologis biasanya mempunyai resiko yang sangat rendah. ${ }^{13}$

Sejalan dengan kompres panas, kompres dingin juga terbukti efektif dalam menurunkan nyeri persalinan. Pada saat penelitian, penulis menemukan satu responden yang tidak mengalami penurunan nyeri. Pada saat ditanyakan, responden mengatakan bahwa tidak merasakan penurunan dari nyeri persalinannya. Ini merupakan salah satu kelemahan dari penelitian ini, dimana, disamping alat ukur yang masih sangat objektif, variabel confounding yang belum dikendalikan seperti suku bangsa, kondisi psikologis, dukungan keluarga, status pekerjaan, dll, juga turut mempengaruhi hasil dari penelitian ini.

\section{Perbedaan Penurunan Derajat Sebelum Dan Setelah Diberikan Kompres Panas Dan Kompres Dingin}

Dari hasil penelitian dapat diketahui bahwa tidak terdapat perbedaan derajat nyeri sebelum diberikan kompres panas dan sebelum diberikan kompres dingin dengan nilai $p$ 0,896.Sedangkan terdapat perbedaan yang bermakna antara derajat nyeri setelah diberikan kompres panas dan setelah diberikan kompres dingin dengan nilai $p$ 0,001.

Sejalan dengan penelitian yang dilakukan Manurung tahun 2011 bahwa tidak terdapat perbedaan derajat nyeri sebelum intervensi dan setelah intervensi pada kelompok kontrol dengan nilai p 0,187. Sedangkan pada kelompok intervensi terdapat perbedaan yang bermakna antara derajat nyeri sebelum diberikan kompres panas dengan setelah diberikan kompres panas nilai $p 0,002{ }^{6}$

Penelitian yang dilakukan Khusniyah tahun 2011 mendapatkan hasil bahwa terdapat perbedaan yang bermakna antara derajat nyeri setelah diberikan kompres panas dan setelah diberikan kompres dingin dengan nilai $p 0,005$. Pada penelitian ini dapat juga disimpulkan bahwa kompres dingin lebih efektif dalam menurunkan nyeri daripada kompres panas dikarenakan penurunan derajat nyeri sebelum dan sesudah kompres panas didapatkan $p=0,003$, sedangkan sebelum dan sesudah kompres dingin didapatkan $p 0,001{ }^{1}$

Kompres panas bersifat vasodilatasi yang meredakan nyeri dengan cara merelaksasi otot. Sedangkan kompres dingin bersifat vasolontriksi yang meredakan nyeri dengan membuat area menjadi mati rasa, memperlambat aliran impuls nyeri dan meningkatkan ambang nyeri seseorang. ${ }^{11}$

Tidak terdapat perbedaan derajat nyeri sebelum diberikan kompres panas dan kompres dingin membuktikan bahwa faktor yang dikendalikan seperti usia, paritas, usia kehamilan dan pembukaan serviks membantu dalam penelitian. Secara garis besar keseluruhan responden sudah dihomogenkan. Sementara terdapat perbedaan derajat nyeri setelah diberikan kompres panas dan kompres dingin, ini membuktikan bahwa terdapat perbedaan yang bermakna antara penurunan nyeri setelah diberikan kompres panas dan setelah diberikan kompres dingin.

\section{Perbedaan Selisih Derajat Nyeri Sebelum dan Setelah Antara Kompres Panas dan Kompres Dingin}

Rerata selisih nyeri sebelum diberikan dan setelah diberikan kompres panas adalah 2,33 $\pm 0,658$, sedangkan rerata selisih nyeri sebelum diberikan kompres dingin dan setelah diberikan kompres dingin adalah 3,38 $\pm 1,117$. Hal ini membuktikan bahwa kompres dingin lebih efektif menurunkan derajat nyeri dibandingkan kompres panas yang terlihat dari nilai rerata penurunan nyerinya lebih tinggi pada kelompok kompres dingin bila dibandingkan dengan kelompok kompres panas.

Berdasarkan hasil uji statistik juga dapat disimpulkan bahwa terdapat perbedaan selisih derajat nyeri sebelum dan setelah diberikan kompres panas dan kompres dingin yang terlihat dari nilai $p \quad 0,001$.

Hasil ini juga sejalan dengan penelitian yang dilakukan oleh Khusniyah tahun 2011, dimana berdasarkan hasil uji statistik Mann Whitney Test didapatkan nilai $p$ 0,005 yang berarti ada perbedaan yang signifikan antara kelompok kompres panas dan kelompok kompres dingin. Perbedaan ini didukung oleh hasil uji Wilcoxon Signed Rank Test pada 
masing-masing kelompok kompres, dimana pada kelompok kompres panas didapatkan nilai $p 0,003$ dan pada kelompok kompres dingin didapatkan nilai $p$ 0,001 yang artinya kelompok kompres dingin lebih efektif dalam menurunkan nyeri daripada kelompok kompres panas. ${ }^{1}$

Efek fisiologis kompres panas adalah bersifat vasodilatasi, meredakan nyeri dengan merelaksasi otot, meningkatkan aliran darah, memiliki efek sedatif dan meredakan nyeri dengan menyingkirkan produkproduk inflamasi yang menimbulkan nyeri. ${ }^{11}$ Panas akan merangsang serat saraf yang menutup gerbang sehingga transmisi impuls nyeri ke medula spinalis dan ke otak dihambat. ${ }^{14}$

Efek fisiologis kompres dingin adalah bersifat vasokontriksi, membuat area menjadi mati rasa, memperlambat kecepatan hantaran syaraf sehingga memperlambat aliran impuls nyeri, meningkatkan ambang nyeri dan memiliki efek anastesi lokal. ${ }^{11}$ Mekanisme lain yang mungkin bekerja adalah bahwa persepsi dingin menjadi dominan dan mengurangi persepsi nyeri.

Manusia merupakan sistem internal yang terbuka dan berinteraksi dengan lingkungan internal maupun eksternal yang dapat menyebabkan stres.Stressor menyebabkan seseorang berinteraksi untuk mempertahankan kesehatannya melalui mekanisme pemecahan masalah atau koping tertentu. Penyebab stress dapat berasal dari diri sendiri, dari luar individu atau karena interaksi dengan orang lain. Pengaruh stressor pada seseorang tergantung pada tingkatan stressor, lamanya stressor serta kemampuan dan keefektifan koping yang digunakan. Maka, dapat disimpulkan bahwa seseorang yang mendapat stressor akan berespon untuk mempertahankan kesehatannya (mengurangi nyeri). Jadi responden menggunakan kopingnya untuk memenuhi kebutuhan rasa nyamannya. ${ }^{1}$ Pada kompres dingin, pengalihan persepsi nyeri yang lebih dominan adalah salah satu tipe transedensi yang telah tercapai sehingga responden merasa lebih nyaman. ${ }^{1}$

Kompres panas tidak mempunyai efek yang sama dengan kompres dingin. Kompres panas hanya meredakan nyeri dengan menyingkirkan produkproduk inflamasi yang menimbulkan nyeri.Kompres panas juga tidak mempunyai efek anastesi lokal.Kompres dingin dapat mengurangi ketegangan otot lebih lama dibandingkan dengan kompres panas. ${ }^{1}$

Pada saat proses penelitian, peneliti juga berpendapat bahwa kompres dingin lebih efektif menurunkan nyeri daripada kompres panas. Respon yang diberikan responden pada saat diberikan kompres dingin lebih cepat dan responden juga kelihatan lebih rileks pada saat diberikan kompres dingin dibandingkan saat diberikan kompres panas.

Berdasarkan teori dan fakta, kompres dingin lebih efektif dalam menurunkan nyeri daripada kompres panas.Dalam pemantauan kala I fase aktif persalinan menggunakan partograf, pemberian kompres dingin juga tidak berpengaruh terhadap kemajuan dan kemunduran persalinan.Pada saat fase aktif dan dilakukan intervensi pengompresan, pembukaan serviks dan kontraksi uterus tetap berjalan dengan normal. Oleh karena itu kompres dingin aman diberikan pada ibu yang sedang dalam proses persalinan dan asuhan sayang ibu juga bisa tercapai.

\section{KESIMPULAN}

Terdapat pengaruh pemberian kompres panas dan kompres dingin terhadap penurunan derajat nyeri kala I fase aktif persalinan fisiologis ibu primipara. Kompres dingin lebih efektif dalam menurunkan derajat nyeri dibandingkan dengan kompres panas

\section{UCAPAN TERIMA KASIH}

Penulis mengucapkan terima kasih kepada STIKes Prima Nusantara Bukittinggi atas kesempatan yang diberikan untuk melanjutkan pendidikan.Kepada BPM Bunda dan BPM Rita Bukittinggi sebagai tempat penelitian atas fasilitas yang telah diberikan.Kepada Dr. dr. Masrul, M.Sc. Sp.GK dan dr. Detty Iryani, M.Kes. M.Pd.Ked. AIF sebagai pembimbing atas masukan dan bimbingan dalam menyelesaikan tesis ini.

\section{DAFTAR PUSTAKA}

1. Khusniyah Z. Efektifitas stimulasi kulit dengan teknik kompres hangat dan dingin terhadap penurunan persepsi nyeri persalinan kala i fase aktif persalinan fisiologis. 2011 (diunduh 2 
September 2013). Tersedia dari: URL:

HYPERLINK http://www.journal.unipdu.ac.id/ indexphp/eduhealth

2. Maryunani A. Nyeri dalam persalinan tekhnik dan cara penanganannya. Jakarta. Trans Info Media; 2010.

3. Shoorab N, Zagami S, Mirzakhani K, Mazlom S. The effect of intravenous fentanyl on pain and duration of the active phase of first stage labor. Oman Medical Journal. 2013;28(5):306-10.

4. Update on Nonpharmacologic approaches to relieve labor pain and prevent suffering. journal of midwifery \& women's health.Simkin, P, Bolding A, April. 2004. Tersedia dari: URL: HYPERLINK http://www.jmwh.org

5. Price S. Patofisiologi konsep klinik proses proses penyakit. Jakarta: EGC; 2006.

6. Manurung S. Pengaruh tekhnik pemberian kompres hangat terhadap perubahan skala nyeri persalinan pada klien primigravida. 2011 (diunduh 28 Desember 2013). Tersedia dari: URL:HYPERLINK http://www.journal.unipdu.ac.id

7. Dolatian M, Hasanpour A, Montazeri S, Hesmat $R$, Majd $A$ The effect of reflexology on pain intensity and duration of labor on primiparas. 2011. Tersedia dari: URL: HYPERLINK http:/www.ircmi.com
8. Liu, David TY. Manual persalinan. Edisi ke-3. Jakarta. EGC; 2008.

9. Yani D, Khasanah U. Pengaruh pemberian kompres air hangat terhadap rasa nyaman dalam proses persalinan kala 1 fase aktif. 2012 (diunduh 2 September 2013). Tersedia dari: URL: HYPERLINK http://www.journal.unipdu. ac.id

10. Novitasari D, Astuti P. Pengaruh pemberian kompres hangat terhadap nyeri persalinan kala 1 fase aktif pada ibu primigravida Di BPS Sri Hidayati Candi Bandungan and Sri Widayati Banyu Kuning Bandungan. 2011 (diunduh 2 September 2013). Tersedia dari: URL: HYPERLINK http://perpusnwu.web.id/shared/ biblio view.php

11. Berman A. Buku ajar praktik keperawatan klinis. Jakarta: EGC; 2009.

12. Tamsuri A. Konsep dan penatalaksanaan nyeri. Jakarta: EGC; 2007.

13. Smeltzer S, Bare, Brenda G. Buku ajar keperawatan medikal-bedah. Jakarta: EGC; 2002.

14. Potter P, Perry Anne G. Fundamental of nursing fundamental keperawatan. Jakarta: Salemba Medika; 2010. 